\title{
THE IMPLEMENTATION OF PROJECT-BASED LEARNING \\ IN TEACHING WRITING OF PROCEDURAL TEXT
}

\author{
Vina Aini Salsabila \\ Suryakancana University \\ vnsabila91@gmail.com
}

\begin{abstract}
This study aims to identify how project-based learning can help develop students' writing ability in the form of procedural text. The study used a qualitative case study design. The data were collected through classroom observation, students' writing, and interview which were analyzed qualitatively. The data show that PBL can develop students' writing ability in which students improve their capacity in the concept of procedural text involving social function, schematic structure, and linguistic features.
\end{abstract}

Key Words: Project-based learning, writing, procedural text

\section{INTRODUCTION}

Writing skill plays an essential role in English learning (Thitivesa, 2014). It is a productive skill that allows students to get more chances for processing language (Harmer, 2007). Writing skill is a reflection of ideas, opinion, and thought. It is also a needed skill in composing essay in most academic courses (Bailey, 2004).

Although writing is considered as an important skill, writing seems difficult and challenging for students (Harmer, 1992). Among four skills in English, most of students are difficult to get a good score in writing. It is supported by the result of preliminary study in a junior high school conducted by the writer. The result shows that most of students get low score compared with other skills. Hence, it is necessary to teach writing skill effectively.

The demand of applying effective instructions in teaching English, including writing skill, is stated in the latest curriculum of Indonesia. According to Regulation of Ministry of Education number 32 year 2013, The process of teaching should be 
conducted for the sake of reaching the standard of learning outcome which is considered as the goal of teaching learning process. Hence, the instructions should be interactive, inspiring, entertaining, challenging, and motivating to make students actively participate. It also should give the opportunity for students to develop their creativity and independence according to their talent, interest, and physical and psychological growth.

According to the demand of applying an effective instruction above, it is essential to organize instructions by selecting suitable methods. One of the methods which fulfill the aforementioned criteria of good instruction is project-based learning (henceforth it will be mentioned as PBL). PBL is an instruction approach that shifts traditional teaching practices into long-term activities, which are student-centered, and integrated with real-world issues and practices (Solomon, 2003; Staff, 2001; Willie, 2001 as cited in Tiangco, 2006).

In line with the previous statement, PBL has been proven as an effective method applied in teaching learning process. There are several studies which show positive results of PBL implementation. A study of Baş (2011) shows that students taught by PBL method were more successful in learning and had higher attitude levels towards the lesson. This study indicated that PBL is a recommended teaching method in order to succeed students' learning achievement. The study is also strengthened by a study of Foss, Carney, McDonald, \& Rooks (2006) which shows project-based instruction as a viable and flexible alternative to traditional intensive English coursework.

Additionally, PBL makes students aware of their own English ability and improve English skills in real life contexts (Lam, 2012; Poonpon, 2011). PBL also develops problem-solving ideas, gained academic knowledge, and finally completed the project successfully in a high motivation (Chang, 2014; Hilvonen and Ovaska, 2010). In addition, Simpson (2011) proves that PBL can enhance learning skills such as teamwork, high-order thinking and presentations skills, and self-confidence which promote students' autonomy focusing on the process of learning.

Meanwhile, PBL is also effective to be applied to enhance four skills of English (Poonpon, 2011). It is even applied for specific skill such as studies which have been 
conducted by Fitria (2013), Maulany (2013), and Maulida (2013) which highlight that project-based learning can be implemented in English speaking skill. Although PBL is considered as an important method, research on project-based learning related to teaching writing skill is still limited. Thus, this study tries to fill the gap in explaining how project-based learning can help students develop their writing ability and describing students' opinion in regards to the implementation of PBL in teaching of writing procedural text.

According to the issues above, this study tries to investigate the contribution of project-based learning to students' writing development of procedural text.

\section{THEORETICAL FRAMEWORKS}

Project-based learning is defined by some experts (Foss et al., 2006), for instance, Schneider (2005, p. 1) states that PBL is "a teaching and learning model (curriculum development and instructional approach) that emphasizes student-centered instruction by assigning projects". Meanwhile, Solomon (2003) asserts that PBL is an approach to learning and in the process made to develop several skills successively or at the same time as they work on a challenging project. Furthermore, Chikita, Padmadewi, \& Suarnajaya (2013, p.5) affirm that "PBL is the use of classroom project in learning and assessment in order to facilitate students in constructing their meaningful idea and knowledge to the real world".

The definitions of project-based learning above indicate that the use of project is the main core of this teaching method. Hence, it can be said that project-based learning is a teaching method that organizes learning through project assignment (Chard, 2013; Helle, Tynjala, \& Olkinuora, 2006; Schneider, 2005; Termizi, 2009, p. 13; Thomas, 2000).

Project-based learning consists of several stages. At this study, the writer only highlights the stages of Stoller (2002). The stages can be seen in this following figure.

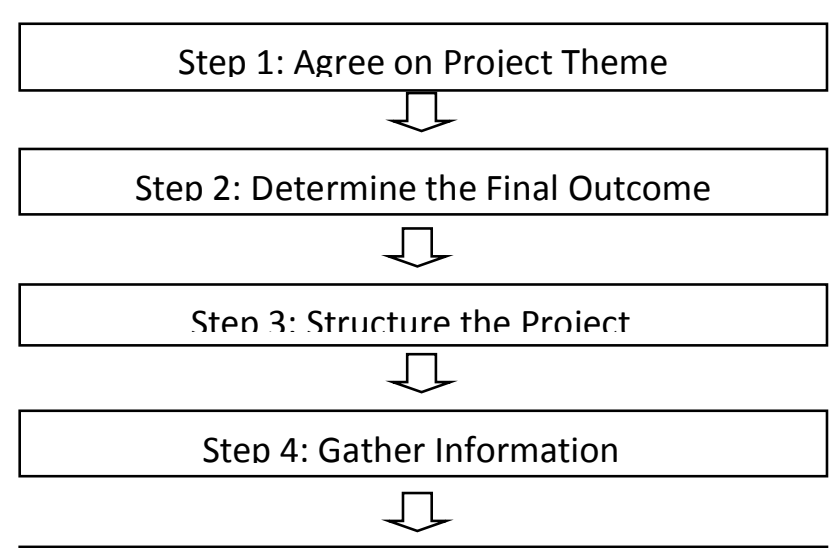


Figure 1. Steps of Project-Based Learning Implementation (Stoller, 2002).

This study focuses on writing procedural text which is a type of text which is frequently found in daily life, such as in a menu or in a recipe. In order to arrange the text well, there should be three aspects of text to be taken into account as follows. The first aspect of the procedure text is seen from its social function. The social function of procedure text is to describe how something is accomplished or to show readers how to do something through a sequence of actions or steps (Emilia, 2013 p. 98; Gerot \& Wignell, 1994 p. 206). The second aspect is the schematic structure. Then the last aspect is the grammatical features of the text.

Another aspect of this genre is its generic structure which covers goal, materials, and steps. Firstly, procedure text is introduced by goal. Goal is written to show the aim of the whole of the text. It is also stated as a prediction of the conclusion that might happens (Emilia, $2013 \mathrm{p}$. 98). The existence of this part is obligatory since it indicates what the text is about. Different from the first generic structure, the second part is not always written in all procedural text (Gerot \& Wignell, 1994, p. 206). It is materials part which contains things or equipments and materials which are used as observed objects in the text (Emilia, 2013 p. 98).

Meanwhile, the third part of organizational structure of procedural text is steps. This part describes a series of steps that need to be conducted in order to complete an experiment or procedure. In other words, these steps are carried out for the sake of achieving the goal (Derewianka, 1990 p.27; Emilia, 2013; Gerot \& Wignell, 1994 p.206). 


\section{METHOD}

This study applied a qualitative study since it is in line with the definitions of qualitative study mentioned by Creswell (2008) and Nunan (1992). Firstly, a qualitative study uses the researcher as the key instrument of the study. Secondly, it focuses on the description of particular activity without comparing the attitudes or behaviors of people. Thirdly, this study involves interpretive discussion, interpretive meanings, and multiple sources which is in line with Creswell (1994, 2008), Fraenkel and Wallen (1990), and Yin (2011).

Moreover, this study was considered as a case study design since it revealed how PBL developed students' writing skill which was observed in an ongoing process. The study emphasized the process instead of the result. Hence, the result was described descriptively and simultaneously which is in line with the criteria of a case study mentioned by Creswell (1994).

This research was undertaken at a private Islamic Junior High School in West Bandung, West Java, Indonesia. The choice of this site came from two reasons. Firstly, having been teaching for two years at the school, the researcher got an easy access to the research site. It is in line with Bogdan and Biklen (1992) who state that the easy way to access the research site makes the researcher easy to conduct the research. The teaching program was created for the students of class seven in a junior high school. The students participated in this study based on their English teacher's recommendation. There were thirty students involved in this study. However, there were only three students who became the focus of the study who represented high achieving, middle achieving, and low achieving students.

There were three techniques to collect the data of this study. The techniques consist of classroom observation, students' texts, and interview. In this study, the researcher acted as an observer for eight meetings of the teaching program. The length of an implementation meeting came from the steps of PBL, which consisted of seven stages suggested by Stoller (2002). The teaching program was designed according to the basic principles of project-based learning.

Moreover, the students' texts were in the form of procedural text. These texts were collected from two steps of teaching program in order to reveal how project-based learning stages helped students develop their writing skill. Firstly, the students' texts consisted of three samples were collected from the diagnostic writing. These three samples were selected purposively to represent high achieving, middle achieving, and low achieving students. Secondly, three samples of students' texts were obtained from last drafts of their writing. Hence, 
there were six texts used in this study. Those six texts were considered as representative texts since the texts had shown considerable developments in some aspects of text.

Interview was defined as "an interaction between two people, with the interviewer and the subject acting in relation to each other and reciprocally influencing each other" (Kvale, 1996 p. 35 cited in Emilia, 2005). It was an essential technique since it helped the researcher find their real opinion when participants were not able to be observed directly regarding the implementation in detail, which is in line with Creswell (2003).

The data of the present study were obtained from observation, students' texts, and interview. After collecting the data, the researcher analyzed the data qualitatively. Transcribing was conducted to analyze observation data. The result of analysis was done by analyzing students' written texts. Students' texts were analyzed through analytical components mentioned in the previous chapter. Afterwards, the obtained data through interview was coded. The detailed information is described as follows.

For classroom observation, the researcher acted as the program implementer who got closer information in gaining data. During the program, the researcher videotaped the whole activity while she also took a note for collecting valuable data that might not be captured by the recorder. The process of noting what happened in classroom also gave benefit in investigating the contribution of each stage of project-based learning to teaching writing skill.

The data taken from the video tape and note were then analyzed by transcribing, categorizing and analyzing using a thematic analysis, as suggested by Kvale (1996). The thematic analysis covered the investigation of the implementation of project-based learning in teaching procedural text. Hence, the analysis revealed the detailed information in order to answer the research questions descriptively.

For students' text analysis, after collecting three samples of students' writing text which were obtained from high, middle, and low achieving student), the researcher started to analyze the texts in terms of the schematic structure and linguistic features based on the theory of SFLGenre Based Approach with reference to Butt et al. (2000), Derewianka (1990), Derewianka \& Jones (2012), Emilia (2011), and Gerot and Wignell (1994. The general information regarding this analysis tools was described in chapter 2. The analysis only focused on the aspects of procedural genre which consisted of schematic structure, social function and grammatical features. The analysis of grammatical features only focused on the transitivity system to realize 
ideational meanings applied in the text and the use of temporal conjunction, as mentioned by Gerot and Wignell (1994).

At last, in order to analyze data obtained from the interview, transcribing and categorizing process were performed, as suggested by Creswell (2003). It was accomplished to acquire relevance between the results of data to the proposed research questions which covered the implementation of project-based learning.

Furthermore, the data from classroom observation were triangulated with the data from the text analysis and interview to answer the first research question. Additionally, the answer of the second research question was taken from the data from interview which was triangulated to the classroom observation. This triangulation data was organized to increase the validity of making research conclusion, as described by Emilia (2013).

\section{FINDINGS AND DISCUSSION}

This section provides the detailed analysis and interpretation of texts obtained from the teaching program. It is presented to answer the research question "What is the contribution of Project-Based Learning to students' writing development?".

\section{Enhancing Students' Awareness on Social Function of Procedural Text}

Text 1, the example of student's independent writing, which was written by a high achieving student, is provided in Table 1. It is divided into clause forms.

Table 1. High achieving student's text (Text 1)

\section{How to Make Banana Chocolate}

Goal

1. I want to tell you about how to make banana chocolate 


\section{Materials}

2. you will need:

- 2 Bananas p, 200 gr chocolate, 100 gr butter, messes, milk, knife, wok, plate

Steps

3. Then, you will do:

4. First, slice banana and cut (it) but do not (cut) very small.

5. Second, put oil on the wok (,) wait until (the) oil is hot.

6 . Third, put (the) banana on the wok carefully.

7. Fourth, lift banana and wait for a moment.

8. Fifth, put (the) banana on the plate.

9. Sixth, spread banana with some butter.

10. Seventh, sow messes and chocolate on the banana.

11. Eight, sow milk chocolate on the banana

12. Finally, serve it

In terms of social function, Text 1 was started with the use of a phrase "How to Make Banana Chocolate" which indicates the intention of giving information about what the text will be about, as described by Emilia (2013 p.98). In this text, the writer tried to tell the reader about how to make banana chocolate as it appeared obviously from the title of the text. The awareness of social function of the procedural text was also found in texts written by middle and low achieving students. The writers re-emphasized the social function of the text in the first paragraph that led to the conclusion that the writer had understood what the procedural text is aimed to.

It is in line with Emilia (2013 p. 98) and Gerot \& Wignell (1994 p. 206) who state that the social function of procedure text is to describe how something is accomplished or to show readers how to do something through a sequence of actions or steps.

\section{Enhancing Students' Awareness on Schematic Structure of Procedural Text}

In the Text 1 , the writer introduced the goal of the text by stating a complete sentence "I want to tell you how to make banana chocolate". It indicates that writer seemed successful in sharing information about the goal of the text in appropriate heading, as mentioned by Derewianka (1990 p.27). The improvement of students' ability in writing the information was the result of the establishment of gathering information. The stage was successful in make the student gain ideas 
of the text. In gathering information stage, the student was encouraged to find out their own ideas about the theme of a text in the content of the project, as mentioned by Stoller (2002). It is also in line with the student's opinion about the process of writing the goal of the text as follows.

$\mathrm{T}$ : What did you do in this meeting (gathering information stage)?

$S$ : I decided the title of my text.

$\mathrm{T}$ : Do you find it difficult?

S : hmm.. At first I felt difficult, but after I interviewed my friend about her favorite food, I found idea about the goal of my text.

The excerpt shows that the process of finding idea was obtained through interviewing friends which was part of gathering information. In this activity, the student was encouraged to interview her friend about the background knowledge of the field and the theme of the text. Hence, through interviewing people, the student conducted real-world activity. It is relevant to the basic principle of PBL, i.e. PBL as a real-world activity which helped the student develop the writing ideas (Solomon, 2003; Staff, 2001 as cited inTiangco, 2006). Thus, stages of projectbased learning, especially for gathering information stage, seemed to be effective to be applied in teaching procedural text.

In the second part, the student listed the needed materials to make banana chocolate. The student tried to tell the readers about the detail materials that should be prepared by stating, "to make Banana Chocolate, you will need...milk.". The use of that sentence reflected that the writer succeeded in showing the materials as the part of schematic structure of procedural text as suggested by Derewianka (1990 p.27), Emilia (2013 p.98), and Gerot \& Wignell (1994 p.206). Furthermore, the student also added the information of materials by telling the sum of materials needed in making the banana chocolate such as 2 bananas, 200gr chocolate, and 100 gr butter, which showed that the writer successfully got into developing level of writing, which is in line with Derewianka (1990 p.27), Emilia (2013 p.98), and Gerot \& Wignell (1994 p.206). The development of writing the procedural text reflected that the process of gathering information that had been conducted by the students made students successful in getting sufficient information in completing the text. Furthermore, it also shows that the teacher succeeded to tell students about how to make an appropriate writing while they listed the materials similar to the sample text in modeling session.

At the next part, the writer went on the paragraph by mentioning steps that should be passed in making banana chocolate. She gave instructions to the readers in detail. It emphasizes that she could control the schematic structure of the procedural text consistently. In this case, she was 
successful in writing steps of making something that were connected to the materials and goal of the text, as suggested by experts, such as Derewianka (1990 p.27) and Emilia (2010 p.98).

To sum up, the development of students' writing ability in the terms of schematic structure could be found in students text of high, middle, and low achievers. The summary can be seen in table 2 .

Table 2. Summary of Schematic Structure of student's texts

\begin{tabular}{|c|c|c|c|}
\hline \multirow{2}{*}{ Text } & \multicolumn{3}{|c|}{ Schematic Structure of Texts } \\
\cline { 2 - 4 } & Goal & Materials & Steps \\
\hline Text 1 & $\sqrt{ }$ & $\sqrt{ }$ & $\sqrt{ }$ \\
\hline Text 2 & $\sqrt{ }$ & $\sqrt{ }$ & $\sqrt{ }$ \\
\hline Text 3 & $\sqrt{ }$ & $\sqrt{ }$ & $\sqrt{ }$ \\
\hline
\end{tabular}

\section{Enhancing Students' Awareness on Grammatical Features of Procedural Text}

This part explains student's improvements in writing procedural text as the result of the project in terms of its grammatical features. The grammatical features analyzed in these texts are the use of simple present tense, temporal conjunction, material process, adverb of manner, and technical words that might be found in the text.

\section{Table 3. Middle achieving student's text (Text 2)}

Aim
1. How to make milor
Materials
2. You will need noodle, egg, leek, salt, oil
Steps
3. First, slice leek.
4. Second, boil noodle with to boil (boiled) water.
5. After that, remove water (from) noodle.
6. Put noodle into a bowl.
7. After that, put egg into bowl.
8. After that, put slice leek and salt into a bowl.
9. Stir (it) until (it) mix (is mixed).
10. Then, heat oil into wok.
11. Then, put batter into wok.
12. After become (ing) brown, flip milor.
13. After milor cooked, put on a plate.


14. Finally, you can eat milor.

Table 4. Low achieving student's text (text 3)

Aim
1. How to make seblak lumpia
Materials
2. You need :
$-\quad$ Lumpia
$-\quad$ Noodle
$-\quad$ Egg
$\quad$ - $\quad$ Greater (grater)
$\quad$ - $\quad$ Onying oil
$\quad$ - $\quad$ Chili
Steps
3. First, frin (grind) greater, onion garlic, chili, salt
4. Second, put oil into wok
5. Third, fry seasoning to (into) oil hot (hot oil)
6. After that, put (enough) water
7.Past (then), (add) noodle and egg
8. Then, stir noodle and egg
9. Put seblak (into) lumpia
10.After that, lumpia fill (fill lumpia) with seblak
(and) fold (it)
11. Last, fry seblak lumpia into wok
12. Finally, serve it

In Text 2 and Text 3, the writers knew that procedural text usually applies simple present tense in almost all of the sentences. It can be seen from their consistency in applying verb 1 in each sentence of the "steps" part such as put, turn, and boil. The writer seemed easy to hold on the consistency of writing first verb and using imperative sentences such as mentioning put water into a pan and turn (on) the stove. Hence, the students were successful in reaching the learning goal of the teaching program that required her to write a consistent use of tense in the text.

Moreover, Text 2 and Text 3 applied a correct heading in separating the schematic structure of the text. However, similar to high achieving student, middle and low achievers could not show temporal conjunction as the indicator of sequence of activity that they tried to tell the readers. They separated the series of steps by using period without being added by connector or the use of a number of activities. It indicates that the writers seemed to be struggling to understand the need of adding the connection between sentences in a series of steps. The failure of understanding the use of conjunction in writing the procedural reflects the requirement of teaching grammar 
repeatedly. Hence, the teacher needs to teach grammar more than one time in order to help students develop their writing.

Meanwhile, at the first sentence of text 2, the writer showed the goal of the text by writing How to make milor in the form of present tense. It is also reflected in the next sentence of material part, i.e. you will need. Even until the last part of the text, the writer could apply the first verb, as the characteristics of the simple present tense, put in the beginning of imperative sentence. The use of imperative sentence can also be seen from the omission of subject that becomes the typical command sentence, as suggested by Derewianka (2011 p.112). It is also emphasized by Derewianka (1990 p.29), Emilia (2013 p. 99), and Gerot \& Wignell (1994 p. 206) who suggest that procedural text often constitutes simple present tense in imperative or command form.

Furthermore, for the transitivity system, the writers successfully wrote the series of activity by preceding the material processes in the beginning of each sentence. As presented in the text, they applied appropriate material process for each sentence such as slice, boil, remove, put, stir, heat, and flip. The use of the material process was presented in this following table:'

\section{Table 5. Process types used in Text 1-3}

\begin{tabular}{|c|c|c|c|c|c|c|}
\hline Type & 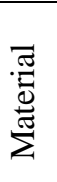 & 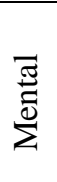 & $\begin{array}{l}\bar{\pi} \\
\stackrel{0}{0} \\
>\end{array}$ & 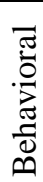 & 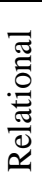 & 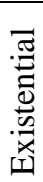 \\
\hline Text 1 & 14 & - & - & - & - & - \\
\hline Text 2 & 14 & 1 & 1 & & & \\
\hline Text 3 & 10 & - & - & & & \\
\hline
\end{tabular}

Table 4 demonstrates the total of process types used in the students' final draft. The development of the amount of material processes reflects that students made a good improvement in writing procedural text in terms of its grammatical features.

Another improvement gained by the students, was found from the use of the temporal conjunction in most of the sentences in the Text 2 and Text 3. They could list a series of action that she tried to tell the readers by utilizing first, second, afterwards, and then. They also showed indicator of the end of activity that should be conducted to make milor by using finally. Hence, it can be concluded that the students had a good control in attaining coherence of the text by stating those various temporal conjunctions in the procedural text, as suggested by Emilia (2010 p. 167). 
Additionally, in the Text 5.4, it appears several technical words related to cooking activity such as bowl and batter. It also indicates their ability in expressing their background knowledge of the field which was taught by the teacher.

\section{CONCLUSION}

The result of students' text analyses of high, mid, and low achiever indicated some improvements. Those were observed from students' diagnostic writing and the final draft. In regard to Text 1 which was selected to represent high achiever, the result demonstrated the significant improvement in the schematic structure of the text while the writer could construct a complete element of procedural text. Furthermore, she could also increase the amount of the material process in the Text 1 consistently applied the present tense in the text. Text 1 also showed the appropriate usage of the temporal conjunction in the whole text. Hence, the students succeeded in constructing a good text of procedural text.

In addition, student 2 as the sample of middle achieving student, seemed to be successful in constructing a procedural text. In Text 2 , she only produced simple sentence by applying inconsistent tense. On the contrary, in the result of the final text, she could produce consistent use of the simple present tense. She succeeded in adding material processes in the beginning part of a sentence of the whole text. Meanwhile, student 3, as a low-achieving student, seemed to be confused in putting the material process while he still put the material process in the middle of the text after writing goal of sentence. However, he showed significant improvement in the application of temporal conjunctions in the final text.

Overall, each student succeeded in having some improvement in constructing a procedural text. It was seen from the schematic structure and the use of simple present tense, material process, and temporal conjunction in the text which were included as the characteristics of procedural text, as mentioned by Derewianka (1990 p.27), Emilia (2010 p.98), and Gerot \& Wignell (1994 p.206).

\section{REFERENCES}

Bailey, S. (2004). Academic writing: A practical guide for students. New York: Routledge Falmer. 
Baş, G. (2011). Investigating the effects of project-based learning on students' academic achievement and attitudes towards English lesson. TOJNED : The Online Journal Of New Horizons in Education, 1(4).

Bogdan, R., \& Biklen, S. K. (1982). Qualitative research for education: An Introduction to Theory and Methods. Boston: Allyn and Bacon.

Chang, W.-J. (2014). Group communication and interaction in project-based learning: the use of facebook in a Taiwanese EFL context. International Journal of Learning, Teaching and Educational Research, 1(1), 108-130.

Chard, S. (2001). Project leaning. Retrieved from http://www.edutopia.org/chard.html. Accessed on February 8, 2015

Creswell, J.W. (1994). Research Design: Qualitative\& Quantitative Approaches. California: SAGE Publication Inc.

Creswell, J. W. (2008). Research Design: Qualitative and Quanitative Approaches. New Delhi: SAGE Publication Work. Retrieved from https://www.heacademy.ac.uk/sites/default/files/peterdemian.pdf. Accessed on June 11, 2015

Derewianka, B. (1990). Exploring how texts work. Newtown: PETA.

Derewianka, B. (2011). A new grammar companion for teachers (First). Sydney: E:lit.

Derewianka, B. (2003). Trends and issues in genre-based approaches. RELC Journal, 34, 133154. Retrieved from http: //doi.org/10.1177003368820303400202. Accessed on June 17, 2015

Derewianka , B., \& Jones, P. (2012). Teaching Language in Context. Melbourne: Oxford University Press.

Emilia, E. (2005). A Critical Genre-Based Approach to Teaching Academic Writing in a Tertiaty EFL Context in Indonesia, 1. Retrieved from https://minervaaccess.unimelb.edu.au/handle/11343/39548. Accessed on January 20, 2015

Emilia, E. (2011). Pendekatan genre based dalam pengajaran bahasa inggris: Petunjuk bagi guru. Bandung: Rizqi Press.

Emilia, E. (2013). A synthesis of approaches to teaching writing: A case study in an Australian primary school. Pakistan Journal of Social Science, 33(1), 121-135. Retrieved from http://www.bzu.edu.pk/PJSS/Vol33No12013/PJSS-Vol33-No1-11.pdf. Accessed on January 11,2015

Fitria, S. (2013). Speaking activities in young learners classroom: the implementation of projectbased learning approach. Skripsi. Universitas Pendidikan Indonesia, Bandung.

Foss, P., Carney, N., McDonald, K., \& Rooks, M. (2006). Project-based learning activities for 
short-term intensive English programs.Retrieved from

https://www.academia.edu/1592331/Project-based_learning_activities_for_shortterm_intensive_English_programs. Accessed on 11 January 2015

Fraenkel, J.R., \& Wallen, N.E. (1990). How to design and evaluate research in education. San Fransisco: McGraw-Hill

Gerot, L., \& Wignell, P. (1994). Making sense of functional grammar. Sydney: Gerd Stabler.

Harmer, J. (1992). The practice of english language teaching. London: Longman.

Harmer, J. (2007). How to teach English. Essex, UK: Pearson Education Limited.

Helle, L., Tynjala, P., \& Olkinuora, E. (2006). Project-based learning in post-secondary education - theory, practice and rubber sling shots. Higher Education, (51), 287-314.

Hilvonen, J., \& Ovaska, P. (2010). Student motivation in project-based learning. International Conference on Engaging Pedagogy.

Kvale, S. (1996). Interviews: An introduction to qualitative research interviewing. London: SAGE Publications Ltd.

Lam, P. S. (2012). Project-based learning. In Seel, P.D. (Ed.), Encyclopedia of the Sciences of Learning (pp. 2707-2709). USA: Springer US. Retrieved from http://link.springer.com/referenceworkentry/10.1007/978-1-4419-1428-6_1095

Maulida, N. (2013). Speaking assessment technique using project-based learning. Skripsi. Universitas Pendidikan Indonesia, Bandung.

Nunan, D. (1992). Research method in language learning. New York: Cambridge University Press.

Nunan, D. (2003). Practical English language teaching. Singapore: McGraw Hill.

Poonpon, K. (2011). Enhancing English skills through project-based learning, English Teacher Journal, 40(10), 1-10

Schneider, D. K. (2005, November 18). Project-based learning. Retrieved from http://edutechwiki.unige.ch/en/Project-based_learning

Simpson, J. (2011, May). Integrating project-based learning in an english language tourism classroom in a thai university. Thesis. Australian Catholic University. Retrieved from http://dlibrary.acu.edu.au/digitaltheses/public/adt-acuvp309.29062011/02whole.pdf. Accessed on January 4, 2015

Stoller, F. L. (2002). Project work: A means to promote language and content. In Richards, J.C. \& Renandya, W.A (Eds.). Methodology in Language Teaching: An Anthology of Current Practice, 107-120.Cambridge: Cambridge University Press 
Termizi, M. (2009). The effect of project-based learning on pre-service teachers' environmental knowledge, attitude and behaviour. Master thesis, Universiti Sains Malaysia. Retrieved from http://pustaka2.upsi.edu.my/eprints/192/. Accessed on January 2, 2015

Thitivesa, D. (2014). The academic achievement of writing via project-based learning. World Academy of Science, Engineering and Technology International Journal of Social, Management, Economics and Business, Engineering 8(9).

Thomas, J. W. (2000, March). A review of research on project-based learning. Retrieved from http://www.newtechnetwork.org.590elmp01.blackmesh.com/sites/default/files/dr/pblrese arch2.pdf

Tiangco, J. A. N. (2006). Project-based learning (pbl) assessment for efl/esl instruction: the philppine experience and its implications to taiwan. Retrieved from http://fllcccu.ccu.edu.tw/conference/2006conference/chinese/download/C39.pdf. Accessed on January 11, 2015

Yin, R.K. (2011). Qualitative research from start to finish (Kindle). New York: The Guilford Press. 